\title{
On the historical
}

legitimacy of the

October Revolution

Sobre a legitimidade

histórica da Revolução de Outubro

\section{David Mandel*}

ABSTRACT: This article discusses the question of the historical legitimacy of the October Revolution. Was it an arbitrary act carried out behind the back of the people and that diverted Russia from its normal path of development toward a liberal democracy? That is the dominant position today in the historiography, one also supported by the Russian government. Or was rather it a popular revolution, with deep roots in Russian history and society?
RESUMO: Este artigo discute a questão da legitimidade histórica da Revolução de Outubro. Foi ela um ato arbitrário, realizado à revelia do povo, que desviou a Rússia de sua via normal de desenvolvimento em direção a uma democracia liberal? Essa é a posição dominante hoje na historiografia, defendida também pelo governo russo. Ou, ao contrário, foi uma revolução popular, com raízes profundas na história e na sociedade russa?

Palavras-chave: Revolução de Outubro, legitimidade histórica, bolcheviques Keywords: October Revolution, historical legitimacy, Bolsheviks 


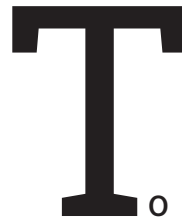

argue in support of the historical legitimacy of the October Revolution and of the suppression of capitalism that followed is to go against the currently dominant viewpoint in the historiography of the revolution, as well as the position of the present Russian government. Of course, to defend the historical legitimacy of October is not to claim it was inevitable. Nothing in the history of a people is inevitable. There are always alternative paths of development, especially in periods of revolutionary crisis. But a liberal-democratic path of development- and that was the aim of the February Revolution, even among workers - was not a choice available to Russian society. Yet, that is the argument, explicit or implicit, of those who would deny legitimacy to the October Revolution.

What does one mean by "historical legitimacy"? Above all it means that October was not an arbitrary act organized behind the back of Russian society by a group of

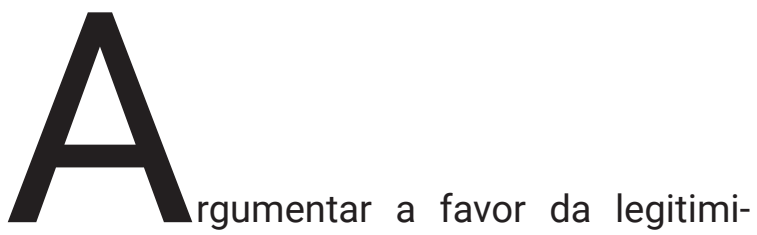
dade histórica da Revolução de Outubro e da subsequente supressão do capitalismo significa contrariar o ponto de vista correntemente dominante na historiografia da revolução, assim como a posição do atual governo russo. Obviamente, defender a legitimidade histórica de Outubro não implica afirmar a sua inevitabilidade. Na história de um povo, nada é inevitável. Há sempre formas alternativas de desenvolvimento, em particular nos períodos de crise revolucionária. Para a sociedade russa, entretanto, uma via de desenvolvimento liberal-democrática - e era esse o objetivo da Revolução de Fevereiro, mesmo entre os operários - não foi uma escolha possível. Não obstante, esse é o argumento, explícito ou implícito, daqueles que viriam a negar a legitimidade da Revolução de Outubro.

0 que se quer dizer, afinal, com "legitimidade histórica"? Acima de tudo, que Outubro não foi uma ação arbitrária organizada à revelia da sociedade russa por um grupo de ideólogos

\footnotetext{
* This paper is a version of a talk presented at the launching in Moscow of the author's book: Петроградские рабочие в реовлюциях 1917-года (февраль 1917 -- июнь 1918 гг.) Москва, Хронограф 2015. An English version of this book will be published in 2107 by Haymarket Press in the United States and a French version by Syllèpse in France.

David Mandel is a professor of political science at the Université du Québec à Montréal. He is the author of many books and articles on the Soviet and Russian working class and labour movements and has actively participated in labour education in Russia, Ukraine and Belarus. E-mail: mandel.mark-david@uqam.ca

Este artigo é uma versão de uma apresentação oral realizada em Moscou, no lançamento do livro de D. Мandel: Петроградские рабочие в реовлюциях 1917-года (февраль 1917 - июнь 1918 гг.) Москва, Хронограф 2015. Em 2017, será publicada uma versão em inglês desse livro pela Editora Haymarket, nos Estados Unidos, e uma versão em francês pela Syllèpse, na França.

David Mandel é Professor de Ciência Política na Université du Québec à Montréal e autor de diversos livros e artigos sobre os sovietes, a classe operária russa e movimento operário. David Mandel também tem participado ativamente da formação sindical na Rússia, Ucrânia e Bielorrússia. E-mail: mandel.mark-david@uqam.ca
} 
Marxist ideologues who were bent on carrying out, at any price, a "socialist experiment". That is how the October Revolution is presented in a draft "Concept of the New Educational-Methodological Complex on National History," ordered by the present Russian government. In that document one can read, for example, that "The Great Russian Revolution that occurred in 1917, and also the "Soviet experiment" that began in October 1917, by their impact on world processes, are recognized as some of the most important events of the twentieth century." ${ }^{11}$ The February Revolution is still thus considered "great" (although it did overthrow the Tsar, whom the presentday Russian Church has elevated to sainthood, while among the people, sinful as it was, he was daubed "Nikolai the Bloody"). But October is reduced to an "experiment", in other words to an arbitrary act that deviated Russia from its natural path of development, presumably one of capitalist democracy.

My own research into the revolutionary period ${ }^{2}$ supports the conclusion that October was indeed a popular revolution. For workers and peasants, its aim was to save February's democratic revolution from the threat of counterrevolution at the hands of the propertied classes, the bourgeoisie and the aristocratic landowners. And since this second revolution was directed against those classes and was led by the workers'

1http://rushistory.org/wp-content/uploads/2013/11/2013.10. 31-Концепция_финал.pdf. (site of the Russian Historical Society, consulted Feb. 2, 2014.)

${ }^{2}$ This text is largely based on D. Mandel, The Petrograd Workers in the Revolutions of 1917 (February 1917-June 1918), Brill and Haymarket Press, to appear in 2017. marxistas que se empenharam em realizar, a qualquer preço, um "experimento socialista". É assim que a Revolução de Outubro é apresentada no projeto de lei "Concepção do Novo Sistema Metodológico-Educacional sobre a História Nacional", encomendado pelo atual governo russo. É possível ler nesse documento, por exemplo, que "A Grande Revolução Russa que ocorreu em 1917, assim como o experimento soviético que teve início em Outubro de 1917, por seu impacto nos processos mundiais, são reconhecidos como um dos mais importantes acontecimentos do século XX" ${ }^{1} \mathrm{~A}$ Revolução de Fevereiro é ainda assim denominada de "grande" (embora tenha deposto o tsar, hoje elevado a santidade pela Igreja Russa, mesmo que o povo, pecador que era, o tenha alcunhado então de "Nicolau, o sanguinário"). Mas a de Outubro é reduzida a um "experimento"; em outras palavras, a uma ação arbitrária que desviou a Rússia de seu trilho natural de desenvolvimento, presumivelmente o da democracia capitalista.

Minha pesquisa sobre o período revolucionário ${ }^{2}$ apoia a conclusão de que a Revolução de Outubro foi de fato uma revolução popular. Para os operários e os camponeses, seu objetivo era salvar a revolução democrática de Fevereiro da ameaça da contrarrevolução por parte das classes proprietárias, a burguesia e a aristocracia fundiária. E o fato de essa segunda revolução ter sido dirigida contra estas classes e liderada pelo movimento operário, desencadeou uma dinâmica econômica e política que levou à supressão do capitalismo.

${ }^{1}$ http://rushistory.org/wp-content/uploads/2013/11/2013.10.

31-Концепция_финал.pdf. (website da Sociedade Histórica Russa. Acesso em: 2 de fev. 2014.)

2 Este texto é amplamente baseado em The Petrograd Workers in the Revolutions of 1917 (February 1917-June 1918), de D. Mandel,Editora Brill and Haymarket, a ser publicado em 2017. 
movement, it unleashed economic and political dynamics that led to the suppression of capitalism.

The historical experience of capitalist democracy shows that a necessary condition is that the bourgeoisie not consider that its socio-economic dominance - or any other interest that it might consider vital in the given circumstances - is threatened by the democratic freedoms. There is involved, therefore, a certain subjective element: the perception on the part of the bourgeoisie of the degree of threat to what it considers vital to its dominance. Be that as it may, this condition was absent in Russia of the early twentieth century. The Russian bourgeoisie, and the nobility even more, feared to remain face to face with the toiling classes, the workers and peasants, without the support of the repressive apparatus of the autocratic state.

Russian society was deeply split, polarized between the propertied classes, on the one hand, and the toiling classes, on the other. This polarization, this irreconcilable opposition had deep roots in the history and social structure of Russian society. It was not something that the Bolsheviks created in October 1917. "We are accused of sowing civil war," said a Bolshevik worker at the conference of worker and Red-army delegates of the First City District of Petrograd in May 1918. "There is here a big mistake, if not a lie... Class interests are not created by us. They are a question that exists in life, a fact, before which all must bow." ${ }^{3}$

\footnotetext{
3 Pervaya konferentsiya rabochikh i krasngvardveiskikh deputatov 1-go gorodksovo raiona, Petrograd, 1918, p. 248.
}

A experiência histórica dos últimos dois séculos mostra que uma condição necessária para a democracia capitalista é que a burguesia não considere que seu domínio socioeconômico - ou qualquer outro interesse que ela possa considerar vital em dadas circunstâncias - esteja ameaçado pelas liberdades democráticas. Há, portanto, um certo elemento subjetivo envolvido: a percepção, por parte da burguesia, do grau de ameaça daquilo que ela considera vital para a sua dominação. Seja como for, essa condição era inexistente na Rússia do início do século XX. A burguesia russa, e mais ainda a nobreza, temiam permanecer frente a frente com as classes trabalhadoras - com os operários e os camponeses - sem o apoio do aparato repressivo do estado autocrático.

A sociedade russa estava profundamente polarizada: de um lado entre as classes proprietárias e, de outro, as classes trabalhadoras. Essa polarização, essa oposição irreconciliável, tinha raízes profundas na estrutura social e histórica da sociedade russa. Não foi algo criado pelos Bolcheviques em outubro de 1917. "Acusam-nos de termos semeado a guerra civil", declarou, em maio de 1918, um operário bolchevique na Conferência de Delegados Operários e do Exército Vermelho do Primeiro Distrito da Cidade de Petrogrado. "Há nisso um grande erro, senão uma mentira... Os interesses de classe não foram criados por nós. É uma questão inerente à vida, um fato ao qual todos devem se submeter." ${ }^{\prime 3}$

O medo do povo explica a oposição covarde e fundamentalmente impotente à autocracia até mesmo por parte dos elementos mais radicais das classes dominantes. V. A. Maklakov, membro dos Kadetes (Partido Constitucionalista

\footnotetext{
3 Pervaya konferentsiya rabochikh i krasngvardveiskikh deputatov 1-go gorodskogo raiona. Petrograd, 1918, p. 248.
} 
Fear of the people explains the cowardly, fundamentally impotent opposition to the autocracy even among the most radical elements of the propertied classes. The Kadet (Constitutional Democrat - liberal) V.A. Maklakov expressed this graphically in a famous article entitled "A Tragic Situation", published in 1915. He used a metaphor to explain his point. An automobile is travelling along a mountain road, and the driver is obviously crazy. The threat of a catastrophe is great. There are people sitting in the car (read: liberal political actors)who know how to drive. But their action is paralyzed by the fear that in the course of the struggle to get control of the steering wheel, the car will fall into the abyss. And your mother (Russia, clearly identified with the social dominance of the propertied classes) is seated in the back. This fear paralyses the action of those "who know how to drive."4 J. M. Paleologue, French ambassador to Russia during the war, recalled a conversation in June 1915 with the prominent banker and industrialist A.I Putilov. The latter described the coming revolution as "horrifying anarchy, endless anarchy... anarchy for ten years."

When the workers of Petrograd, supported by the garrison, overthrew the autocracy in February 1917, the propertied classes at first, so it seemed, welcomed the revolution. Their members came out into the streets sporting red ribbons in their lapels. But in their hearts, they were deeply alarmed. V.V. Stankevich, a Popular (rightwing) Socialist, military commissar under the Provisional

\footnotetext{
${ }^{4}$ Russkie vedomosti, no, 221, 1915.

${ }^{5}$ Cited in M. Mitel'man, B. Glebov, and A. Ulyanskii, Istoriya Putilovskogo zavoda 1801-1917 gg., Leningrad, 1926, p. 33.
}

Democrático, de orientação liberal), expressou claramente essa condição em um famoso artigo intitulado "Uma situação trágica”, publicado em 1915. Para expor o seu ponto de vista, ele usou a seguinte metáfora: Um automóvel está trafegando por uma estrada montanhosa, conduzido por um motorista visivelmente louco. 0 risco de uma catástrofe é iminente. No automóvel há passageiros (leia-se: atores políticos liberais) que sabem dirigir. Mas a ação deles é paralisada pelo medo de que, na disputa pelo controle do volante, o automóvel caia no precipício. Pois no banco de trás encontra-se sua mãe (leia-se: a Rússia, claramente identificada com a dominação social das classes proprietárias). Esse temor impede a ação daqueles "que sabem dirigir"4. J. M. Paleologue, embaixador francês na Rússia durante o período da guerra, teve uma conversa com o importante banqueiro e industrial A. I. Putilov em junho de 1915 , em que Putilov descreveu a iminente revolução como "anarquia hedionda, anarquia sem fım... anarquia por dez anos". ${ }^{5}$

Quando os operários de Petrogrado, apoiados pela guarnição, derrubaram a autocracia em fevereiro de 1917, as classes proprietárias, num primeiro momento, pareciam saudar a revolução. Seus membros saíam às ruas ostentando fitas vermelhas em suas lapelas, enquanto no coração sentiam-se profundamente alarmados. V. V. Stankiévich, socialista popular (da ala de direita), comissário militar do Governo Provisório de 1917 e astuto observador do cenário político, assim retratou esse período: "Oficialmente, estavam exultantes. Saudavam a revolução, bradavam 'viva' aos

\footnotetext{
${ }^{4}$ Russkievedomosti. № 221, 1915.

${ }^{5}$ Citado em M. Mitel'man, B. Glebov, and A. Ulyanskii, Istoriya Putilovskogozavoda 1801-1917. Leningrad, 1926, p. 33.
} 
Government in 1917 and an acute observer of the political scene, recalled of that period: "Officially they were jubilant. They praised the revolution, shouted "hurray" for the fighters for freedom, decorated themselves with ribbons and marched under red banners. They are said "we", "our" revolution, "our" victory. But in their hearts, in intimate conversation, they were horrified, they shuddered and felt themselves captives of hostile elemental forces that were going along some unforeseeable path." ${ }^{\text {"6 }}$

A fundamental condition of liberal democracy was thus missing: the propertied classes were too afraid of the popular masses. Did they have anything to fear? The landed aristocracy without question did. The peasants' conception of land reform and peasants constituted the overwhelming majority of the population - would put an end to their existence, not only as a dominant class, but as a class per se. But neither could the bourgeoisie be indifferent to the perspective a land reform as the peasants wanted it - without compensation - since it would violate the sacrosanct inviolability of private property, even if the property in question was feudal in origin. Besides, by 1917 a very significant part of landlord land was mortgaged to the banks, a fact that brought the two propertied classes even closer together. ${ }^{7}$

But the workers, including the most radical ones, members of the Bolshevik party,

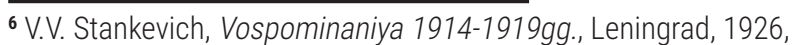
p. 33.

${ }^{7}$ By the start of 1917, the banks held as much in mortgages to the landowners as they had loaned out to all of industry. T.V. Osipova, Rossiskoekres'yanstvo v revolyutsii I grazhdanskoivoiny?Moscow, Streletz, 2001, pp. 7-8. guerreiros da liberdade, adornavam-se com tiras e marchavam sob bandeiras vermelhas. Diziam 'nós', 'nossa' revolução, 'nossa' vitória. Não obstante, em seus corações, em suas conversas íntimas, estavam horrorizados, sobressaltados e sentindo-se reféns de forças hostis e incontroláveis, que seguiam um caminho imprevisível." ${ }^{\text {" }}$

Inexistia na Rússia uma condição fundamental para a democracia liberal: as classes dominantes tinham muito medo das massas populares. Havia motivo para esse temor? Para a aristocracia fundiária, sem dúvida, havia. A reforma agrária, na concepção dos camponeses - estrato amplamente majoritário da população russa -, colocaria um fim em sua existência não apenas enquanto classe dominante, mas também enquanto classe social. Mas a burguesia também não poderia ficar indiferente à perspectiva de uma reforma agrária como a que queriam os camponeses sem nenhuma compensação -, já que ela violaria a sagrada inviolabilidade da propriedade privada - ainda que a propriedade em questão fosse de origem feudal. Além disso, em 1917, grande parte das terras dos senhores fundiários estava hipotecada pelos bancos, o que garantiu maior aproximação das duas classes proprietárias. $^{7}$

Entretanto, em Fevereiro de 1917, nem mesmo os operários mais radicais, membros do partido bolchevique, tinham como objetivo a derrubada do capitalismo. Essa deveria ter sido uma Revolução liberal-democrata. Seus

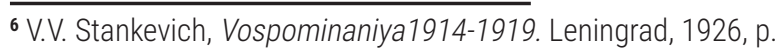
33.

${ }^{7}$ No início de 1917, os bancos concentravam em hipotecas aos latifundiários tanto quanto a soma integral de todos os empréstimos às indústrias. T.V. Osipova, Rossiskoekrest'yanstvo $\mathrm{V}$ revolyutsii I grazhdanskoivoiny, Moscow, Streletz, 2001, pp. 7-8.
} 
were not aiming at the overthrow capitalism in February 1917. That revolution was supposed to be liberal-democratic. Its popular goals were: a democratic republic; an energetic diplomacy aimed at rapidly concluding a democratic, just peace; the eight-hour workday; and land reform. The last two goals were without doubt social. And they were not the only ones. As one of the Petrograd Soviet's agitators explained in March 1917: "The workers can't obtain freedom and not use it to ease their burden of labour, to fight capital. ${ }^{8 \prime}$ Besides the introduction of the eight-hour workday, in the days after the February Revolution, the workers purged the factory administrations of their most odious members (under the Tsar, the factory administration had collaborated intimately with the civil and political police and was notoriously despotic); they sought increases to their wages (which had been seriously eroded by wartime inflation); they sought the right to elect representatives to permanent factory committees that would represent them in dealings with the administration (the owners had stubbornly resisted permanent collective representation of the workers in their factories), and they obtained the right of their elected factory committees to "oversee the internal work rules" in the factories. Finally, hiring and dismissal of workers were to be carried out with the consent of the factory committee -this had been another area of unbridled managerial arbitrariness before the revolution.

This was undoubtedly a lot, especially for Russia. But workers were not thinking to threaten capitalism with these measures.

${ }^{8}$ Pravda, Mar. 17, 1917 objetivos populares eram: uma república democrática; uma diplomacia enérgica, que visava a estabelecer rapidamente uma paz justa e democrática; a jornada de trabalho de oito horas diárias; e a reforma agrária. As duas últimas reivindicações eram, sem dúvida, sociais - e não eram as únicas. Como declarou, em março de 1917, um dos agitadores do soviete de Petrogrado: "Os operários não podem obter a liberdade sem que possam usá-la para aliviar a sua carga de trabalho, para combater o capital." ${ }^{8}$ Nos dias seguintes à Revolução de Fevereiro, além da implementação da jornada diária de oito horas, os operários expurgaram as administrações fabris de seus mais execráveis membros (durante o regime tsarista, a administração das fábricas, notoriamente despótica, colaborou substancialmente com a polícia civil e política). Adicionalmente, os operários exigiram aumentos de salários (que haviam sido corroídos pela inflação no período da guerra). Também reivindicaram o direito de eleger representantes para as comissões permanentes das fábricas, para representá-los nas negociações com a administração (os proprietários reincidentemente resistiam à representação coletiva permanente dos operários em suas fábricas), e obtiveram o direito de eleger comissões para "supervisionar as regras internas de trabalho" nas fábricas. Por último, os processos de admissão e demissão de operários passariam a ocorrer com a anuência das comissões de fábricas - essa era uma outra área em que havia uma arbitrariedade gerencial desenfreada antes da revolução.

Isso, sem dúvida, era muito, especialmente para a Rússia. Contudo, a intenção dos operários, com essas medidas, não era ameaçar o capitalismo. Nem os trabalhadores nem os

${ }^{8}$ Pravda, 17 de mar., 1917. 
Neither the workers, nor the Bolsheviks put forth the demand for workers' control (with the partial exception of workers in state-owned enterprises.) And when they did later do that, they were demanding access to information, not participation in management of the factories.

The more enlightened representatives of the bourgeoisie understood that. Speaking to a meeting of the Council of Private Railroads in March 1917, N.V. Nekrasov, Minister of Railways and a leftist among liberals, tried to calm the fears of the assembled: "There is no need to fear the fact that social elements are now beginning to appear. One should rather strive to direct these social elements in the right direction... A rational combination of the social moment with the political is essential, and in no circumstances to deny the social moment, to fear it... That which we need to achieve is not a social revolution, but the avoidance of social revolution through social reform."

At first, it seemed that the industrialists were prepared to heed this advice. But, in fact, they considered the concessions they had made in the wake of the revolution to be only temporary, until the workers revolutionary ardour cooled and the concessions could be taken back. Only a few weeks after the revolution, the bourgeois (non-socialist) press began to write of the workers' "excessive demands" that were threatening supplies to the valiant soldiers in the trenches. Workers immediately saw in this an attempt to drive a wedge between them and soldiers - it was the worker-solider

${ }^{9}$ Rech', Mar, 29, 1917, bolcheviques se puseram a exigir o controle operário (exceto parcialmente os operários das empresas estatais nas primeiras semanas da revolução). E posteriormente, quando isso ocorreu, a exigência era por acesso à informação, e não por participação no gerenciamento das fábricas.

Os representantes mais esclarecidos da burguesia compreenderam isso. Ao discursar numa reunião do Conselho das Ferrovias Privadas em março de 1917, N. V. Nekrássov, ministro das Ferrovias e um esquerdista entre os liberais, tentou acalmar os ânimos da assembleia: "Não há motivos para temer o fato de que os elementos sociais agora começam a aparecer. Antes, é preciso um esforço para direcionar esses elementos para o lado certo... É essencial uma combinação racional do momento social com o político, e de modo algum negar o momento social, temê-lo... Não é uma revolução social que almejamos, mas evitar a revolução social através da reforma social." ${ }^{\prime 9}$

A princípio, os industriais pareciam dispostos a seguir esse conselho. Mas, na verdade, eles consideravam que as concessões que haviam feito logo após a revolução, apenas temporariamente, poderiam ser tomadas de volta tão logo o ânimo revolucionário dos trabalhadores arrefecesse. Algumas semanas após a revolução, a imprensa burguesa (isto é, não socialista) começou a alardear a respeito das "demandas excessivas" dos operários, que ameaçavam o abastecimento dos valorosos soldados nas trincheiras. Os operários imediatamente interpretaram esse fato como uma tentativa de provocar uma ruptura entre eles e os soldados - a Revolução de Fevereiro só fora possível com a aliança entre operários

${ }^{9}$ Rech', 29 de mar., 1917. 
alliance that had made possible the February Revolution. They began to suspect that, behind increasingly frequent production problems, a hidden, creeping lockout was being put into effect. Before the revolution, lockouts had been a favourite weapon of the industrialists against the workers' movement. The general lockout in St. Petersburg in November and December 1905 had dealt a decisive blow to Russia's first revolution.

The workers suspicions only grew stronger when they saw the Provisional Government refuse to adopt any serious measures to combat the growing economic dislocation caused by the war and Tsarist incompetence. The Minister of Trade and Industry, A.I. Konovalov, himself an industrialist, resigned in protest against a rather modest plan for state economic regulation that had been drafted by the Economic Commission of the Petrograd Soviet, controlled at the time by the moderate socialists, the Mensheviks and the Socialist Revolutionaries (SRs). These parties strongly advocated the political alliance with the liberal bourgeoisie. A few weeks later, in a speech to a Congress of the War-Industry Committees, Konovalov complained about of the workers' "excessive demands" and warned that "if in the nearest future a sobering of minds does not occur, we will witness the closure of tens and hundreds of enterprises." ${ }^{10}$ And Konovalov was known as a "leftist" among industrialists.

And so already from the late spring of 1917 , workers were becoming increasingly convinced that the bourgeoisie was conducting

${ }^{10}$ Novaya zhizn', May 19, 917 e soldados. Eles começaram a suspeitar que, por trás dos problemas cada vez mais frequentes de produção, urdia-se um insidioso locaute. Esta arma, antes da revolução, foi um meio favorito dos industriais contra o movimento operário. Em novembro e dezembro de 1905, o locaute geral em São Petersburgo havia assestado um golpe decisivo contra a primeira revolução russa.

A desconfiança dos operários tornou-se ainda maior diante da recusa do Governo Provisório de adotar medidas sérias para combater a crescente desorganização econômica provocada pela guerra e pela incompetência do regime tsarista. A. I. Konovalov, ministro do Comércio e da Indústria, e também um industrial, demitiu-se em protesto contra um plano bastante moderado para a regulação econômica estatal, elaborado pela Comissão Econômica do Soviete de Petrogrado - controlada, naquele período pelos socialistas moderados, os mencheviques e os socialistas revolucionários (SRs), partidos que defendiam fortemente uma aliança política com a burguesia liberal. Algumas semanas depois, num discurso para o Congresso dos Comitês da Indústria Bélica, Konovalov reclamou das "demandas excessivas" dos operários e advertiu que: "se, em um futuro próximo, não ocorrer um desembriagamento da razão, seremos testemunhas do fechamento de dezenas e centenas de empresas". ${ }^{10} \mathrm{E}$ olha que Konovalov era conhecido como um "esquerdista" entre os industriais.

E, assim, já no fim da primavera de 1917, os operários estavam cada vez mais convencidos de que a burguesia tramava dissimuladamente um locaute, na esperança de esmagar o

${ }^{10}$ Novaya zhizn', 19 de maio, 1917 
a hidden lockout, hoping to suppress the workers' movement with "the bony hand of hunger", as the liberal banker and industrial magnate P.P. Ryabushinskii so graphically put it at the Second All-Russian Congress of Trade Industry Congress in early August 1917. Against the threat of advancing economic collapse and mass unemployment, the workers tried to introduce control of the administration, in the sense of access to information in order to verify the causes cited by management for production problems. But they soon realized that such control would evade them unless the bourgeoisie was removed from influence in the government. And so it was no accident that the first citywide assembly of workers' representatives in the capital to vote for the transfer of power to the soviets was the Conference of Factory Committees that met at the beginning of June.

The transfer of power to the soviets meant for the workers the removal of the propertied classes from influence over state policy. Workers were increasingly convinced that the propertied classes were bent on counterrevolution. The Provisional Government, a coalition of representatives of those classes with the moderate socialists, during the eight months of its existence failed to carry out a single one of the objectives that popular classes had sought in the February Revolution: not land reform, not a peace policy, not convocation of a constituent assembly; not the adoption of a law on the eight-hour workday. (The latter was introduced by the workers in the capital on their own. But a law was never adopted.) Instead, the Provisional Government, pressed by the Allies, launched a new offensive at the front movimento dos trabalhadores com "a esquelética mão da fome", como declarou, de forma bastante ilustrativa, o magnata industrial $P$. P. Ryabushinski, no início de agosto de 1917, durante o II Congresso Pan-Russo da Indústria e do Comércio. Contra a ameaça do colapso iminente da economia e o desemprego em massa, os operários procuraram introduzir o controle da administração das fábricas, a fim de terem acesso à informação e verificar as causas alegadas pelos gestores acerca da crise de produção. Contudo, logo perceberam que não teriam acesso a esse controle enquanto a burguesia continuasse a ter influência no governo. Com efeito, não por acaso, a primeira grande assembleia dos representantes dos operários na capital, que votou pela transferência do poder aos sovietes, foi a Conferência dos Comitês de Fábricas, ocorrida no início de junho.

Para os trabalhadores, a transferência do poder aos sovietes significava o afastamento da influência das classes dominantes na política estatal. Os trabalhadores estavam cada vez mais convencidos de que as classes proprietárias almejavam indubitavelmente a contrarrevolução. O Governo Provisório, uma coalizão dos representantes daquelas classes com os socialistas moderados, durante seus oito meses de existência, não conseguiu cumprir uma reivindicação sequer das exigidas pelas classes populares na Revolução de Fevereiro: nem reforma agrária, nem política pacífica, nem convocação de uma assembleia constituinte, nem a adoção de uma lei sobre a jornada diária de oito horas de trabalho (demanda esta introduzida pelos próprios operários na capital, sem que, contudo, fosse adotada uma lei). Ao contrário, pressionado pelos aliados, 0 Governo Provisório lançou uma nova ofensiva 
in June. It rejected state economic regulation and fought against workers' control. And it abetted and facilitated a generals' conspiracy at the end of August 1917aimed at suppressing popular organizations, the soviets first of all.

Russia's workers fully supported the October insurrection and the transfer of power to the soviets. In the removal of the propertied classes from any influence on government policy they saw the only possibility of avoiding a counterrevolution and realizing the promise of the February Revolution. They did not expect miracles from the transfer of power to the soviets. They saw that industrial collapse and hunger were approaching. And the Bolsheviks, on their part, did not promise miracles.

In the Russian capital, the workers, and first of all worker Bolsheviks, who numbered more than 30,000 in October 1917 understood that they would have ranged against them not only have the propertied classes, but also most of the intelligentsia, the educated elements of society, including the socialist intelligentsia. The latter, with significant but too few exceptions, turned its back on the people at the very moment it dared to straighten its bent back and stand at full height. But the transfer of power to the soviets offered at least a chance to save the revolution. And there was also the hope that Russia's example would inspire revolutions in Western countries, and that the latter would come to the aid of Russia's revolution.

The Bolsheviks are often condemned for organizing the October insurrection and for unleashing civil war, when, in fact, they no fronte em junho, rejeitou a regulação econômica estatal e se posicionou contra o controle dos trabalhadores. Além disso, encorajou e facilitou uma conspiração de generais em fins de agosto de 1917, com o objetivo de suprimir as organizações populares, e em primeiro lugar os sovietes.

Os operários russos resistiram plenamente à insurreição de outubro e à transferência do poder aos sovietes. Livrar-se da influência das classes dominantes sobre as políticas do governo era a única maneira de evitar a contra revolução e realizar as promessas da Revolução de Fevereiro. Eles não esperavam milagres com a transferência do poder aos sovietes. Eles viam claramente que o colapso da indústria e a fome se aproximavam. E os bolcheviques, por sua vez, também não prometeram milagres.

$\mathrm{Na}$ capital russa, os trabalhadores, e em primeiro lugar os trabalhadores bolcheviques, que em outubro de 1917 eram mais de 30.000 , compreenderam que seus opositores não se restringiam apenas às classes dominantes, mas também à maior parte da intelligentsia (o estrato ilustrado da sociedade), incluindo a intelligentsia socialista. No exato momento em que o povo decidiu dar um basta à sua submissão, a intelligentsia - com expressivas, porém raras exceções - Ihe virou as costas. Mas a transferência de poder aos sovietes oferecia ao menos uma chance de salvar a revolução. Ademais, havia também a esperança de que 0 exemplo da Rússia inspirasse revoluções nos países ocidentais, envolvidos numa guerra imperialista criminosa, e que estes viessem em auxílio à revolução russa.

Os bolcheviques, frequentemente acusados de organizar a insurreição de outubro e de 
deserve praise for their action in October. As a workers' party, they honestly carried out their duty - they did not abandon the people at the most critical moment, leaving it without leadership. In contrast, the left Mensheviks, who shared basically the Bolsheviks' view of the counterrevolutionary aspirations of the propertied classes, decided to stand aside, since they did not believe that a government based solely on the soviets, that is, on the workers and peasants, and without participation of the middle strata of society, would be viable. But these middle strata in 1917, and most importantly their educated element, the intelligentsia, had chosen the side of bourgeoisie, or else they vainly tried to stand above the fray. As for the right-wing Mensheviks and SRs, they continued to insist on including in power, in one form or another, representatives of the bourgeoisie - after all, they argued, it was a bourgeois-democratic revolution, the only one possible in backward Russia - closing their eyes to the counterrevolutionary aspirations of the propertied classes.

Those who consider the Bolsheviks a group of ideologues and usurpers have trouble explaining how such a group, without any experience in state or economic administration, without the support of the bulk of the educated part of society, without an army (at least in the first several months), was able to hold onto power against the propertied classes not only of Russia, but of all the more developed capitalist countries, and even some undeveloped ones.

In fact, the Bolshevik party of 1917 was flesh of the flesh of the working class. That was the secret of its success. It was provocar a guerra civil, merecem, antes, o justo reconhecimento por sua ação. Como partido operário, eles cumpriram honestamente o seu dever: não abandonaram a população em seu momento mais crítico, deixando-a sem liderança. Em contrapartida, os mencheviques de esquerda, a despeito de compartilharem com os bolcheviques basicamente o mesmo ponto de vista a respeito das aspirações contrarrevolucionárias das classes proprietárias, decidiram se colocar à parte, já que não acreditavam que um governo baseado unicamente nos sovietes, isto é, nos operários e camponeses, sem a participação dos estratos médios da sociedade, pudesse ser viável. Entretanto, em 1917, esses estratos intermediários da sociedade, e em primeiro lugar o seu elemento educado, a intelligentsia, ou escolheu o lado da burguesia ou procurou, em vão, ficar fora da briga. Por fim, os mencheviques de direita, bem como os socialistas revolucionários, continuaram a insistir a favor da inclusão, de um modo ou de outro, de representantes da burguesia no poder - afinal, argumentavam, essa era uma revolução democrático-burguesa, a única possível num país atrasado como a Rússia - e fechavam os olhos às aspirações contrarrevolucionárias das classes dominantes.

Aqueles que consideram os bolcheviques como um bando de ideólogos e usurpadores, certamente têm dificuldades de explicar como um grupo sem qualquer experiência de administração do Estado ou da economia, sem o apoio da parte educada da sociedade e sem um exército (pelo menos nos primeiros meses), foi capaz de aceder ao poder contra as classes proprietárias não só da Rússia, mas de todos os países capitalistas mais desenvolvidos, e até mesmo de alguns subdesenvolvidos. 
very far from the later image of a "Leninist party," portrayed as an authoritarian, strictly hierarchical organization of professional revolutionaries. If the party had be such in October 1917, there never would have been a second revolution. Only the pressure of the party's lower and middle strata forced the reluctant Central-Committee majority to act in October. The Central Committee went so far as to burn Lenin's letters demanding preparation of the insurrection!

Three fourths of the Bolshevik party membership in Russia's capital $(40,000$ members in October 1917) were workers. The members of the district and city committees were overwhelmingly workers. These worker Bolsheviks were the most active, politically aware and determined part of the working class. They were that part of the working class that dared to take on the leadership of the revolution, knowing that the chances of victory were not great. They had above all a strongly developed sense of dignity - human and class dignity - and they were determined not to yield without giving battle.

It was to these Bolsheviks that Lenin appealed in October against the majority of the party's Central Committee. The latter preferred to await the constituent assembly (elections to which were finally organized by the Soviet government in November), as if that assembly could magically cure the profound split in Russian society. The Kornilov uprising at the end of August 1917, sympathy for which the Kadet party, which was hegemonic among the propertied classes in 1917, did not conceal, demonstrated clearly the kind of regime that latter desired.
De fato, o partido bolchevique de 1917 era carne da carne da classe operária. E esse foi o segredo de seu sucesso. Estava muito distante da imagem posterior que se formou do "partido leninista", retratado como uma organização autoritária, hierarquicamente rígida, de revolucionários profissionais. Se o partido fosse assim, nunca teria ocorrido uma segunda revolução. Foi a pressão dos estratos inferiores e médios do partido que forçou a maioria relutante dos membros do Comitê Central a agir em outubro. 0 Comitê Central chegou ao cúmulo de incinerar as cartas de Lênin que exigiam os preparativos para a insurreição!

Em Petrogrado, três quartos dos membros do partido bolchevique (que somavam 40.000 em outubro de 1917) eram trabalhadores. Os membros dos comitês distritais e municipais, em sua esmagadora maioria, eram operários. Os operários bolcheviques nas indústrias constituíam o segmento mais ativo e politicamente mais consciente e determinado da classe trabalhadora; a parcela que teve a ousadia de assumir a liderança da revolução, embora ciente de que as chances de vitória não eram grandes. Acima de tudo, tinham um senso de dignidade profundamente elevado - de dignidade humana e de classe -, e estavam determinados a não ceder sem lutar.

Foi a esses bolcheviques quem Lênin apelou em outubro contra a maioria do Comitê Central do partido, que preferiu aguardar a assembleia constituinte - eleições que, enfim, seriam realizadas pelo governo dos sovietes em novembro -, como se essa assembleia pudesse resolver, como num passe de mágica, a cisão profunda na sociedade russa. No fim de agosto de 1917, o levante de Kornílov, pelo qual os kadetes, partido hegemônico entre as classes 
One often encounters the claim in the historiography that the roots of Stalinist totalitarianism were already present in the "Leninist" conception of the party. But the party in 1917 was an open, democratic organization. The capital's Bolsheviks more than once rejected positions adopted by the Central Committee and supported by Lenin.

As for the totalitarian tendencies ascribed to the party, one need only recall the unanimous support among Petrograd's Bolsheviks on the morrow of the October insurrection for the formation of a broad coalition of all the socialist parties, from the Bolsheviks on the left to the Popular Socialists on the right. How does this fit with the claim that the Bolsheviks aspired to a one-party dictatorship? If that coalition was not formed, it was because the moderate socialists rejected the principle of a government responsible to the soviets, representative organizations of the workers and peasants, to the exclusion representation of the propertied classes. They insisted on including, in one form or another, representatives of the latter and on limiting the Bolsheviks to a minority status in the government, even though the Bolsheviks had constituted the majority at the recent Congress of Soviets of Workers' and Soldiers' deputies. The Mensheviks and SRs were demanding, in effect, to annul the October insurrection and to restore the status quo ante, which had been the reason for the insurrection. When the workers saw that to be the case, they lost interest in the proposed coalition.

But when subsequently the Left SRs decided to participate in the Soviet government and the Peasant Congress decided to merge dominantes, não esconderam sua simpatia, demonstrou claramente o tipo de regime que estes desejavam.

Com frequência se encontra na historiografia a alegação de que as raízes do totalitarismo stalinista já estavam presentes na concepção "leninista" de partido. Mas o partido, em 1917, era uma organização aberta e democrática. Os bolcheviques da capital rejeitaram várias vezes as posições adotadas pelo Comitê Central e defendidas por Lênin.

Quanto às tendências totalitária atribuídas ao partido, basta lembrar o apoio unânime dos bolcheviques de Petrogrado, no dia seguinte à insurreição de outubro, em favor da formação de uma ampla coalizão de todos os partidos socialistas, desde os bolcheviques à esquerda até os socialistas populares à direita. Como se explica então a alegação de que os bolcheviques pretendiam uma ditadura de partido único? Se essa coalizão não foi formada, foi porque os socialistas moderados rejeitaram o princípio de um governo responsável pelos sovietes - organizações representativas dos operários e camponeses -, que excluía a representação das classes dominantes. Os socialistas moderados exigiam reiteradamente a inclusão, de alguma forma, de representantes destes últimos no governo, além de limitar nele a participação dos bolcheviques ao mínimo, a despeito de estes últimos terem sido maioria no então recente Congresso dos Sovietes dos Deputados Operários e Soldados. Com efeito, os mencheviques e os socialistas-revolucionários pretendiam anular a insurreição de outubro e restabelecer o status quo, que fora a razão pela qual ocorrera a insurreição. Assim que isso se tornou claro para os trabalhadores, eles perderam o interesse na proposta de coalizão. 
with the Central Executive Committee of worker and soldier deputies, there was jubilation among workers, including the Bolshevik workers, who were very conscious of the danger of their political isolation and of the tremendous difficulties that confronted the Soviet government. Despite this, the Mensheviks and the SRs, from the very first days of the Soviet government, referred to it only as "the Bolshevik dictatorship".

In actual fact, the Bolshevik organization in the capital almost disappeared in the year following the October insurrection. The politically active workers - and most of these were organized in the Bolshevik party - felt that, now that the people had taken power in its hands, the task was to work in the soviets, in the economic administrations, to organize the Red Army. This is how Konstantin Shelavin, a member of Petrograd's Bolshevik Committee, recalled that period:

A series of responsible, highly qualified comrades who had gone through the school of illegality became infected with an exclusively "soviet" spirit, not to speak of the masses of the younger generation. Even if these comrades did not give full expression to what they were thinking, all of them, nevertheless, had a certain difficulty imagining what, in essence, was left for the party organizations to do after the victory of the proletariat. Some thought that there at least remained agitation and propaganda activities. But they still felt that the real activity now is, for example, to organize the district soviet of the national
Não obstante, quando, logo em seguida, os socialistas-revolucionários de esquerda decidiram participar do governo dos sovietes e o Congresso dos Camponeses decidiu se unir ao Comitê Executivo Central dos Deputados Operários e Soldados, houve enorme entusiasmo entre os trabalhadores, incluindo os trabalhadores bolcheviques, que estavam muito conscientes dos riscos de seu isolamento político e das dificuldades tremendas que $O$ governo dos sovietes enfrentava. A despeito disso, logo nos primeiros dias do governo dos sovietes, os mencheviques e os socialistasrevolucionários referiam-se a ele apenas como "a ditadura bolchevique".

De fato, no ano seguinte à insurreição de outubro, a organização bolchevique em Petrogrado praticamente desapareceu. Os trabalhadores politicamente ativos - e a maioria deles estava organizada no partido bolchevique - consideravam que agora que o povo havia tomado o poder em suas mãos, era preciso trabalhar nos sovietes, nas administrações econômicas e organizar o exército vermelho. Foi assim que Konstantin Shelavin, membros do Comitê Bolchevique de Petrogrado, recordou esse período:

Uma série de camaradas responsáveis e altamente qualificados, que haviam passado pela escola da ilegalidade, foram contaminados por um estado de espírito estritamente "soviético"- sem contar as massas das novas gerações. Mesmo que esses camaradas não expressassem plenamente os seus pensamentos, todos eles, no entanto, tinham uma certa dificuldade em imaginar o que, de fato, caberia às organizações partidárias fazer após a vitória do proletariado. Alguns cogitaram que restaria, ao menos, as atividades 
economy, and certainly not to "ferment" in the district party committee. Indeed, around them everything was churning; the old was being destroyed and the new was being built; sabotage was being fought; the first new soviet state forces were being recruited; the districts were being organized like independent republics with their own commissars - of labour, of education, etc.; the best party forces were being thrown into this whirlwind of construction... When the Vasileostrovskii district soviet moved into a new building on Srednii Prospekt from the 16th Line, they relegated the district party committee to the fifth floor, and their thinking went something along the lines: what sort of particular work can they possibly have now?"1

This was clearly not the behaviour of a party bent on establishing its totalitarian power.

It is always tempting to read history backwards, in this case from Stalin's totalitarian regime to the October insurrection, or perhaps even farther - to Lenin's brochure What Is to Be Done? ${ }^{12}$ Stalinism did not arise, of course, out of nowhere, but out of the social and political conditions that preceded it. But if the Communist party eventually replaced the soviets already during the civil war as the real centre of power, the explanation should be sought in the social

\footnotetext{
11 Shelavin, «Izistorii Peterburgskogo komiteta bol'shevikov v 1918 godu », Krasnaya letopis', no. 2 (26) (1928) p. 111.

12 On the latter, the book by Lars Liih, ,Lenin Rediscovered: What Is To Be Done in Context (http://ouleft.org/wp-content/uploads/ lenin-rediscovered.pdf) is highly recommended. Liih convincingly shows that the ideas in this pamphlet were widely share in social-democratic circles across Europe.
}

de agitação e propaganda. Mas consideravam que a verdadeira atividade agora era, por exemplo, organizar o soviete distrital da economia nacional e de modo algum "fermentar" o comitê partidário distrital. Com efeito, ao redor estava tudo em efervescência; o velho era destruído e se construía o novo; a sabotagem era combatida; recrutava-se as primeiras novas forças estatais soviéticas; os distritos estavam sendo organizados como repúblicas independentes com seus próprios comissários - do trabalho, da educação, etc. As melhores forças do partido eram arremessadas no turbilhão dessa construção... Quando o soviete do distrito de Vassileostrovski mudou-se da $16^{\mathrm{a}}$ Linha para um novo edifício na Avenida Sriédni, o comitê do partido distrital foi relegado ao quinto andar, já que o pensamento deles era mais ou menos esse: "que tipo especial de trabalho poderão ter a partir de agora?". ${ }^{11}$

Sem dúvida, não era o comportamento de um partido empenhado em estabelecer um poder totalitário.

É sempre tentador ler a história retroativamente: no caso, voltando do regime totalitário de Stalin para a insurreição de outubro; ou talvez ainda, antes, para a brochura 0 que Fazer?, de Lênin ${ }^{12}$. O stalinismo, obviamente, não surgiu do nada, mas das condições políticas e sociais que o precedeu. Mas se o Partido

\footnotetext{
11 Shelavin, "Izistorii Peterburgskogo komiteta bol'shevikov v 1918 godu”, Krasnayaletopis'.No 2 (26) (1928) p. 111.

12 Sobre o último, o livro de Lars Liih, Lenin Rediscovered: What Is To Be Done in Context (http://ouleft.org/wp-content/uploads/ lenin-rediscovered.pdf), é fortemente recomendado. Liih mostra de forma convincente que as ideias dessa brochura estavam amplamente difundidas nos círculos social-democratas de toda a Europa.
} 
and political conditions of that period, and not in some kind of ideological DNA of the Bolshevik party.

Victor Serge, a Belgian anarchist who arrived in Petrograd in 1919 and quickly became a supporter of the Soviet government (after the civil war, in the 1920s, he was active in the left opposition to rising Stalinism), wrote the following in 1920 in a letter to his anarchist comrades back home:

The suppression of so-called freedoms; dictatorship backed up if necessary by terror; the creation of an army; centralization for war purposes of industry, food supplies and administration (whence state control and bureaucracy); and finally, the dictatorship of a party. In this fearsome chain of necessities, there is not a single link that is not rigorously conditioned by the one that precedes it and which does not in turn condition the one that follows it.

Serge recognized that such a state, however justified by the goal of saving the revolution, could generate powerful vested interests that would want to maintain it even after the threat of counterrevolution had passed. His response was a call for vigilance, and he expressed the hope that the revolutionary struggle in more developed countries would not be as difficult and as drawn out as in Russia, a country already devastated by the world war, especially if the following revolutions could rely on the support of an already established revolutionary state in Russia. At the same time, he recognized that in the eventual struggle against the power of the bureaucracy
Comunista foi gradualmente sendo substituído pelos sovietes já durante a guerra civil como 0 verdadeiro centro do poder, a explicação deve ser buscada nas condições sociais e políticas daquele período, e não numa espécie de DNA ideológico do partido bolchevique.

Victor Serge, anarquista belga que chegou a Petrogrado em 1919 e logo se pôs a apoiar o governo soviético (depois da guerra civil, durante a década de 1920 , ele teve participação ativa na oposição de esquerda contra a ascensão do stalinismo), em uma carta de 1920 aos seus compatriotas anarquistas, escreveu:

A supressão das assim chamadas liberdades; a ditadura respaldada, se necessário, pelo terror; a criação de um exército; a centralização, para fins bélicos, da indústria, da provisão de alimentos e da administração (por meio do controle estatal e da burocracia); e, finalmente, a ditadura de um partido. Nessa terrível cadeia de imposições, não há um único elo que não seja rigorosamente condicionado pelo que $o$ antecede e que, por sua vez, não seja condicionante do que o sucede.

Serge reconheceu que um Estado desse tipo, ainda que justificado pelo compromisso de salvar a revolução, poderia gerar interesses poderosos para a sua conservação mesmo depois que a ameaça da contrarrevolução tivesse passado. Em resposta ele fez um apelo à vigilância, e expressou a esperança de que, nos países mais desenvolvidos, a luta revolucionária não fosse tão árdua e prolongada como na Rússia - um país já devastado pela Primeira Guerra Mundial -, especialmente se as revoluções seguintes pudessem contar com o apoio de um Estado revolucionário já consolidado na Rússia. Ao mesmo tempo, Serge admitiu que, num eventual confronto contra o poder da 
in Russia, "the Communists may need to resort to profoundly revolutionary activity which will be long and difficult." ${ }^{13}$

Serge's words find surprising echo in those of a Bolshevik worker at a conference of factory committees in Petrograd in January 1918. The industrial situation was already approaching catastrophic, particularly the shortages of fuel and raw materials. The delegates to the conference were unanimous about the need to centralize economic authority so that the scarce resources and the industrial orders could be allocated in a rational manner according to the most urgent needs of the young Soviet state. The Economic Soviet of the Northern Commune had only just been created, and the conference was to consider proposed regulations, according to which orders emanating from that body would be binding on the factory committees. In the course of the discussion, an anarchist delegate proposed an amendment: the orders would be binding, "except in cases where the order contradicts the interests of the working class." To this, the chairperson of the presidium, a Bolshevik worker, answered:

At the time, when we were examining these regulations, we saw the corresponding point and we wanted to insert exactly that reservation. We thought about it. But we didn't insert it into the charter, thinking that the sovnarkhoz [economic council] that we are organizing will not move against us, because it is not a bureaucratically created organ, not appointed from above, but

${ }^{\mathbf{1 3}} \mathrm{V}$. Serge, Revolution in Danger. Writings from Russia.1919-1921. Chicago, Haymarket, 1920, pp. 142-143; 150 burocracia na Rússia, "os comunistas talvez tivessem de recorrer a uma atividade profundamente revolucionária, que seria demorada e penosa". ${ }^{13}$

As palavras de Serge estavam em admirável consonância com as de um operário bolchevique, na conferência dos comitês de fábrica de Petrogrado, em janeiro de 1918. A situação das indústrias já se tornava catastrófica, em particular a escassez de combustível e de matérias-primas. Os delegados da conferência eram unânimes em reconhecer a necessidade de centralizar a autoridade econômica, a fim de que a escassez de recursos e os pedidos das indústrias pudessem ser alocados de maneira racional, de acordo com as necessidades mais urgentes do jovem Estado soviético. O Soviete Econômico da Comuna do Norte acabava de ser criado, e a conferência deveria considerar as regulações propostas, de acordo com as quais as ordens emitidas por este órgão seriam obrigatórias nos comitês de fábrica. No decorrer da discussão, um delegado anarquista propôs uma emenda: as ordens seriam obrigatórias, "exceto nos casos em que fossem de encontro aos interesses da classe operária". A isso, o presidente do Presidium, um operário bolchevique, respondeu:

No momento em que examinávamos esses regulamentos, observamos um ponto correspondente e quisemos inserir exatamente esta ressalva. Pensamos a respeito. Entretanto, não a adicionamos ao estatuto, imaginando que o sovnarkhoz (conselho econômico), que nós estávamos organizando, não haveria de se colocar contra nós, pois não se tratava de um órgão

\footnotetext{
${ }^{13} \mathrm{~V}$. Serge, Revolution in Danger. Writings from Russia.1919-1921. Chicago, Haymarket, 1920, pp. 142-143; 150.
} 
an organ that we ourselves have chosen, that we can recall, and it consists of people that we can remove from their activity... Don't forget that the sovnarkhoz is a class body, based on the class of the proletariat and the poorest peasants, and it seems to us that it is hardly necessary, by inserting such a reservation, to express that kind of lack of confidence in them. If we adopt an attitude of mistrust from the very beginning, then these organs will hardly be able to function correctly... And I think that only an anarchist could propose such an amendment, as they reject any sort of leaders and have absolutely no confidence in them... [But] if these organs really do thus part ways with the masses, then, of course, we will have to introduce such an amendment. And that will not be enough - we will have to overthrow those organs and perhaps make a new revolution. But it seems to us that, for now, the Soviet of People's Commissars is our soviet, and the institutions that it has established are functioning harmoniously together. ${ }^{14}$

What Serge and these workers feared might eventually happen did happen. But when the time came to make a new revolution, the working class, which had already led three revolutions, could not find the strength for a fourth. The decisive factor in the authoritarian development of the Soviet regime was, without doubt, the dispersal of the working class after the October

14 Oktyabr'skaya revolyutsiya i fabzavkomy, vol. IV., St. Petersburg, 2002, pp. 323-24. criado por vias burocráticas, nomeado de cima; mas de um órgão escolhido por nós mesmos, um órgão que nós podíamos anular, composto por pessoas que podiam ser exoneradas por nós... Não se esqueça de que o sovnarkhoz é um organismo de classe, com base no proletariado e no campesinato mais miserável, e nos pareceu que não era necessário inserir aquela restrição, expressar em relação a eles qualquer falta de confiança. Se começarmos já desde o início a adotar uma atitude de desconfiança, esses órgãos dificilmente poderão funcionar corretamente... Tenho por mim que uma emenda dessas só poderia ser proposta por um anarquista, já que eles rejeitam qualquer tipo de líder e não têm neles absolutamente nenhuma confiança... [Mas] se esses órgãos realmente se distanciarem das massas, então, é claro que teremos de introduzir tal emenda. E só ela não será suficiente - teremos que destruir aqueles órgãos e talvez fazer uma nova revolução. Mas, por enquanto, parece-nos que o Soviete dos Comissários do Povo é o nosso soviete, e que as instituições por ele estabelecidas estão funcionando harmoniosamente em conjunto. 14

O que Serge e esses trabalhadores temiam acabou ocorrendo. Quando, porém, chegou a hora de fazer uma nova revolução, a classe operária, que já havia liderado três revoluções, não conseguiu encontrar forças para uma quarta. 0 fator decisivo para o desenvolvimento autoritário do regime soviético foi, sem dúvida, a dispersão da classe operária depois da Revolução de Outubro, o que ocorreu de forma

\footnotetext{
${ }^{14}$ Oktyabr'skayarevolyutsiya i fabzavkomy. Vol. IV. St. Petersburg, 2002, pp. 323-24.
} 
Revolution, something that occurred surprisingly quickly in the very first months after the insurrection. For a quarter century prior to that, the urban working class had been the vanguard of the struggle for democracy in Russia. Not long after October, it practically ceased to exist as an independent political force. The Communist party claimed to represent the working class. And, and least in the first years, it did have in its ranks the best forces of that class. But the party could not substitute itself for the social class as an active socio-political force, one capable of exercising effective control over the state it had brought into existence. surpreendentemente rápida, já nos primeiros meses após a insurreição. Durante os vinte e cinco anos anteriores a esse período, a classe operária urbana fora a vanguarda do movimento pela democracia na Rússia. Pouco depois da insurreição, ela praticamente deixou de existir como uma força política independente. o Partido Comunista reivindicava a representação da classe trabalhadora e, ao menos nos primeiros anos, contou em suas fileiras com as melhores forças dela. Mas o partido não podia substituir a classe, como uma força sociopolítica ativa, capaz de exercer efetivo controle sobre o Estado que ela havia criado.

Tradução: Ednilson Rodrigo Pedroso ${ }^{15}$

\footnotetext{
${ }^{15}$ Mestrando do Programa de Literatura e Cultura Russa da Faculdade de Filosofia, Letras e Ciências Humanas da Universidade de São Paulo, sob orientação da Profa. Dra. Fatima Bianchi.
} 